\title{
Effect of soaking in Jellyfish on some parameters of wheat and lentil seedlings
}

\author{
${ }^{1}$ O. S. Hussein and ${ }^{2}$ O. I. Saleh \\ ${ }^{1,2}$ Natural Products Research Department, National Center for Radiation Research and Technology, Atomic \\ Energy Authority, P.O. Box 29 Nasr City, Cairo, Egypt.
}

\begin{abstract}
The potency of soaking in digested or stock jellyfish on germination of wheat (Triticum aestivium) and lentil (Lens culinaris) seeds was studied. Also, the photosynthetic pigments, ultrastructure of leaves and minerals in the produced seedling were estimated. The results revealed that soaking seeds in digested jellyfish solution recorded the highest germination capacity and germination rate in lentil seeds. Also, improves seedlings height, number of leaves and fresh weight of the produced seedlings than those from soaked in stock jellyfish or in water.

Soaking lentil seeds in stock or digested jellyfish mostly increased chlorophyll $a, b$ and carotenoisds, contrarwisewashappened in wheat seedlings as compared to control values. A great variation in microelements and heavy metals in dry matter of seedlings that were produced from seeds soaked either in stock or digested solution of jellyfish. Some elements increased another decreased and some disappeared in both wheat and lentil seedlings. Also, the ultrastructural examination by transmission electron microscopy of seven days old wheat or lentil leaf revealed no abnormalities but some organelles as ribosomes, vesicle rough and smooth endoplasmic reticulum are higher in micrograph.
\end{abstract}

Keywords: Jellyfish, wheat, lentil, germination, photosynthetic pigments, mineral, leaf ultrastructure.

\section{Introduction}

Jellyfish represents a problem for many vacationers on Mediterranean Sea shore as it stings them. Can dead Jellyfish represent a good source of element? Are Jellyfish can be exploited in agriculture scale? Since jellyfish an organismwhich livesin the sea, mostly it contains important elements that can be used either by soaking in it as in this research or in fertilization, spraying or other uses in the coming research. Fukushi et al. (2003) examined it as bio fertilizer for vegetable fields. They used the dried sludge of Aurelia aurita and noticed that it accelerates the growth of spinach at earlier stage but rather decelerate the growth at later stage. Fukushi et al. (2004) reported that jellyfish fertilizer has high nitrogen, total phosphorus and potassium content than that of Aurelia aurita. They used jellyfish fertilizer in the vegetables and determined its effectontheirgrowth. Mahran, 1972 were divided the essential elements necessary for good plant growth and production into four groups:

Main nutrient or Macro-elements involving N, P K. Elements involving Ca, Mg, and Fe. A little amount of which has an influence onthe increase of plant growth, but whenthe amount exceeds the adequate liimit, it showsno influence on plant growth. Inactive elements, involving $\mathrm{Na}, \mathrm{Al}, \mathrm{Si}$ and $\mathrm{I}$. They have negligible effect on plant growing, although some of these elements have special effect on certain plants, e.g. Silicon on Graminaceous plants. Microelements involving B, Cu, Mn, Zn, Co and Mo. These are needed within very minute amounts for plant growing.

Mengel et al., 2001 reported that any element lacking or not adequately balanced with other nutrients, growth suppression or even complete inhibition may occur. Most micronutrients are involved in the key physiological processes of photosynthesis and respiration (Marshner, 1995; Mengel et al., 2001). Fertilization is one of the most important cultural practices for seedling quality in reforestation as it can accelerate the shoots growth and seedling roots in addition, organic fertilizers used to improve soil quality and to provide nutrients for plant growth (Bokhtair and Sakurai, 2005). Hossain, et al. (2013) recommended that desalinated-dried jellyfish haspotential as an agricultural material to replace herbicides and chemical fertilizers. Lentils are small annual legume of the family (Leguminosae) and its lens-shaped edible seed, which are excellent source of protein and also rich in vitamins, minerals (iron and phosphorus), soluble and insoluble dietary fiber (Ryan et al., 2007). Domestic consumption of it is primarily in soups, salads, casseroles and stews. Also, wheat (Triticum aestivum) is most important food crop; it contributes about $25 \%$ to the total grain production and is part of daily human diet. This work aims to study the effect of seeds soaking in stock liquefied Jellyfish or in digested solution of it on seeds germination, photosynthetic pigments, minerals and ultrastructure of the produced seedlings. 


\section{Materials}

\section{Materialsand Methods}

Jellyfish obtained from Mediterranean Sea Shore, Alexandria, Egypt. The outer layer of Jellyfish head weigh $3-4 \mathrm{~kg}$ was liquefied and preserved in fridge at $15^{\circ} \mathrm{C}$. Preliminary experiment about seeds soaking in liquefied jellyfish in field of agriculture was done to test its effect on germination and growth. Parts of liquefied Jellyfish was digested in pure sulfuric acid and perchloric acid to dryness then diluted with distilled water to use as soaking treatment and to determine minerals constituents in it.

Seeds of wheat as cereals and lentil as legume were obtained from agricultural research center and used for practical experiment. Both of the obtained seeds weredivided into three groups, one group soaked in tap water, the second in digested solution of jellyfish and the last in stock liquefied jellyfish for half an hour.

\section{Methods}

\section{Germination}

Seeds were tested for germination on wet filter paper in darkness at $23 \pm 1^{\circ} \mathrm{C}$.A piece of filter paper placed in Petri dishes, 20 seeds were placed in each dish and covered by lid and left for germination. Germinated seeds were counted for 7 days after initiation; the seed considered germinated just protrusion of radical. Each treatment wasreplicated five times, the following data wasrecorded: Germination rate $(\mathrm{GR})$, germination percentage $(\mathrm{G} \%)$ and Germination capacity $(\mathrm{GC})$ were determined according to the followingequations:

Germination Rate $(\mathrm{GR})=\mathrm{A}+(\mathrm{A}+\mathrm{B})+(\mathrm{A}+\mathrm{B}+\mathrm{C})+(\mathrm{A}+\mathrm{B}+\mathrm{C}+\mathrm{D}+\ldots) / \mathrm{n}(\mathrm{A}+\mathrm{B}+\mathrm{C}+\mathrm{D}+\ldots \ldots \ldots \ldots \ldots)$

Where: $\mathrm{A}=$ no. of seeds germinating at the $1^{\text {st }}$ count

$\mathrm{B}=$ no. of seeds germinating at the $2^{\text {nd }}$ count

$\mathrm{C}=$ no. of seeds germinating at the $3^{\text {rd }}$ count

$\mathrm{n}=$ no. of the count

Germination Percentage $(\mathrm{G} \%)=$ Maximum number of germination $/$ Total number of seeds

Germination Capacity $(\mathrm{GC})=($ Maximum number of germination / Total no. of seeds $) \times 100$

Vegetative characters

The growth parameters measured on seedlings which were grown in sandy loam soil in small pots i.e. shoot height $\mathrm{cm}^{-1}$ measured from base to the tip of the longest leaf and root length $\mathrm{cm}^{-1}$ measured from theroot-shoot junction to the tip of the longest root, leaf number (unit plant ${ }^{-1}$ ), the plant samples weight freshly and after being dried in the oven at $70{ }^{\circ} \mathrm{C}$ till reached constant weight for dry weightestimation.

\section{Chemical Analysis}

The photosynthetic pigments (chlorophyll a and b) and carotenoids were extracted from fresh leaves tissue samples by acetone ( $80 \%)$. The absorbance of chlorophyll a, chlorophyll b and carotenoids measured colorimetrically on shimadzu 120-02 UV/V spectrophotometer in leaves of seven days old seedling according to Metzner (1965) and the concentration wascalculated using Metzner equations. Minerals and heavy metals were determined by atomic absorption spectroscopy, model, Thermo Scientific 'M6' series after high pressure microwave digestion. Test of heavy metals was performed in Central Laboratory of Residual Analysis of Pesticides and Heavy Metals in Food. The elements were detected in samples and in jellyfish solution, and their limits of quantification (LOQ)according to The Reference Lab for Ministry of Agriculture Accredited To ISO/IEC 17025 By Finnish Accreditation Service (FINAS)], Agricultural Research Center, Ministry of Agriculture according to (Sepe et al., 2003), the estimated relative standard deviation of this method is $<15 \%$. Analyses of cations or anions determined according to Black, et al. (1982). Soluble calcium, phosphorus and sulfur determined according to Soltanpour (1991). Sodium and potassium determined by using flame photometer according to Jackson (1973). Total nitrogen determined with Kjeldahl method (McGill and Figueiredo, 1993).

\section{Ultrastructure Examination}

Samples prepared and sliced into fine sector, its diameter about 70 nanometer in Fungi Laboratory, Research Fungi Institution, in Al-Azhar University. Semi thin sections prepared using ultra microtome, were placed on slides, stained and dried on hot plate for 5 minutes. The prepared semi thin sections were examined with photomicroscope. The samples on the girds were examined using a JEOL JEM-100CX electron microscope in NCRRT laboratory and electron micrographs were picked up.

\section{Statistical Analysis}

Data obtained were statistically analyzed by using Costat statistical program software, 1990 and Duncan's multiple range test (Duncan, 1955) was applied at 5\% probability level to compare the differences among time means. 


\section{Results And Discussion}

\section{A-Effect of Jellyfish Soaking on Seed Germination}

Germination rate (GR) and germination capacity (GC) are two important parameters that reflect efficiency of seed germination. Germination percentage $\mathrm{G} \%$ may reflect the reaction rate of plant seeds to their living environment. Effect of soaking in stock or digested Jellyfish solution on GR, G \% and GC of wheat and lentil seeds were described in Table (1). It can be noticed that GR had slightly increased in all soaking treatments of wheat seeds. The values were 0.227 and 0.259 when wheat seedssoaked in digested and stock jellyfish, respectively as compared to control value (0.215). A slight decrease was observed in lentil GR, the values were 0.382 and 0.381 , when seeds soaked in digested and stock jellyfish solution as compared by control (0.397). Different trend was observed in G\% of wheat, seeds that soaked in digested jellyfish had the same value as control soaked in water $(0.84 \%)$, whereas, those soaked in stock jellyfish had decreased slightly to $0.80 \%$ as compared to control. Germination percentage had increased in lentil seeds soaked in digested jellyfish to $0.85 \%$,

the opposite was observed in seeds soaked in stock jellyfish $(0.35 \%)$ compared to control value $(0.45 \%)$.

TABLE 1. Effect of Soaking in Digested or Stock Jellyfish Solution on Germination of Wheat or Lentil Seeds

\begin{tabular}{|c|l|c|c|c|}
\hline \multirow{5}{*}{ Wheat } & GerminationTreatment & Germination Rate (GR) & Germination Percentage (G \%) & $\begin{array}{c}\text { Germination } \\
\text { Capacity (GC) }\end{array}$ \\
\cline { 2 - 5 } & Control & 0.215 & 0.84 & 84 \\
\cline { 2 - 5 } & Digested Jellyfish & 0.227 & 0.84 & 84 \\
\cline { 2 - 5 } & Stock Jellyfish & 0.259 & 0.80 & 80 \\
\hline \multirow{3}{*}{ Lentil } & Control & 0.397 & 0.45 & 45 \\
\cline { 2 - 5 } & Digested Jellyfish & 0.382 & 0.85 & 35 \\
\cline { 2 - 5 } & Stock Jellyfish & 0.381 & 0.35 & 35 \\
\hline
\end{tabular}

Germination capacity seemed stable in wheat seeds soaked in digested jellyfish and had the same value as the control (84), while the wheat seeds soaked in stock jellyfish decreased to 80. On the other hand, GC of control lentil seeds was 45 , this value increased to 85 in those soaked in digested jellyfish and depressed to reach 35 in seeds soaked in stock jellyfish (Table 1).Chun, et al. (2011) evaluated the effect of jellyfish fertilizer on the growth and survival of the seedlings of different tree species in pots. The results showed an increase in the average of the height and the stem diameter growth in the entire tree seedling that treated with jellyfish fertilizer compared to control trees. The use of jellyfish fertilizer may be a practical way of improving the reforestation technique using recycled waste.

\section{B- Effect of Jellyfish Soaking on Seedlings Growth}

The effect of soaking in digested or stock Jellyfish solution on plant length, shoot length,root length, branch number, leaf number, fresh and dry weights of plant are represented in Table (2).The growth parameters of wheat seedling was affected by seed soaking in digested or stock jellyfish where the values of shoot length, fresh and dry weights increased as compared to control.The increase in the obtained results wasinsignificant except in shoot legnth of wheat (increase by about $15 \%$ ). Insignificant results obtained may attribute to young age of seedlings. On the other hand, leaf number wasn't affected by treatments used as shown in Table (2).Most recording results obtained from seedling arise in lentil seeds soaked in digested jellyfish solution higher than control;except for number of branch and dry weight that had values lower than the control. At vice versa, all the parameters decreased in lentil seedlings from seeds soaked in stock jellyfish compared to control values.

Table 2. Effect Of Soaking In Digested Or Stock Jellyfish Solutions On Wheat And Lentil Growth Parameters.

\begin{tabular}{|c|c|c|c|c|c|c|c|c|}
\hline \multirow{4}{*}{ Wheat } & Parameter & $\begin{array}{l}\text { Plant length } \\
\mathrm{cm}^{-1}\end{array}$ & $\begin{array}{l}\text { Shoot } \\
\text { length } \\
\mathrm{cm}^{-1} \\
\end{array}$ & $\begin{array}{l}\text { Root } \\
\text { length } \\
\text { cm }^{-1} \\
\end{array}$ & $\begin{array}{l}\text { Number } \\
\text { of branch } \\
\text { / plant } \\
\end{array}$ & $\begin{array}{l}\text { Number } \\
\text { of Leaves } \\
\text { / plant }\end{array}$ & $\begin{array}{l}\text { Fresh } \\
\text { weight } \\
\text { g }^{-1} \\
\end{array}$ & $\begin{array}{l}\text { Dry } \\
\text { weight } \\
\mathrm{g}^{-1} \\
\end{array}$ \\
\hline & Control & $\begin{array}{l}35.23^{\mathrm{a}} \\
\pm 0.69 \\
\end{array}$ & $\begin{array}{l}19.83^{\mathrm{b}} \\
\pm 0.30 \\
\end{array}$ & $\begin{array}{l}15.41^{\mathrm{b}} \\
\pm 0.54 \\
\end{array}$ & - & $\begin{array}{l}2.00 \\
\pm 0.0\end{array}$ & $\begin{array}{r}3.39^{\mathrm{a}} \\
\pm 1.67 \\
\end{array}$ & $\begin{array}{r}0.37^{\mathrm{a}} \\
\pm 0.07 \\
\end{array}$ \\
\hline & Digested Jellyfish & $\begin{array}{l}31.53^{\mathrm{b}} \\
\pm 0.80 \\
\end{array}$ & $\begin{array}{l}22.80^{\mathrm{a}} \\
\pm 0.64\end{array}$ & $\begin{array}{r}8.72^{\mathrm{a}} \\
\pm 0.69 \\
\end{array}$ & - & $\begin{array}{l}2.00 \\
\pm 0.0\end{array}$ & $\begin{array}{r}3.53^{\mathrm{a}} \\
\pm 1.85 \\
\end{array}$ & $\begin{array}{r}0.86^{\mathrm{a}} \\
\pm 0.19 \\
\end{array}$ \\
\hline & $\begin{array}{l}\text { Stock } \\
\text { Jellyfish }\end{array}$ & $\begin{array}{l}30.87^{\mathrm{b}} \\
\pm 1.18 \\
\end{array}$ & $\begin{array}{l}21.93^{\mathrm{a}} \\
\pm 0.58 \\
\end{array}$ & $\begin{array}{r}8.94^{\mathrm{a}} \\
\pm 0.79 \\
\end{array}$ & - & $\begin{array}{r}2.00 \\
\pm 0.0 \\
\end{array}$ & $\begin{array}{c}6.63^{\mathrm{a}} \\
\pm 0.66 \\
\end{array}$ & $\begin{array}{c}0.54^{\mathrm{a}} \\
\pm 0.16 \\
\end{array}$ \\
\hline & L.S.D 0.05 & 2.70 & 1.55 & 2.02 & - & - & 5.15 & 0.52 \\
\hline & $\mathbf{P}$ & *** & *** & $* * *$ & - & - & ns & ns \\
\hline \multirow{3}{*}{ Lentil } & Control & $\begin{array}{c}24.48^{\mathrm{ab}} \\
\pm 0.85\end{array}$ & $\begin{array}{l}17.33^{\mathrm{a}} \\
\pm 0.80\end{array}$ & $\begin{array}{c}7.14^{\mathrm{a}} \\
\pm 1.24\end{array}$ & $\begin{array}{c}3.67^{\mathrm{a}} \\
\pm 0.24\end{array}$ & $\begin{array}{c}9.22^{\mathrm{a}} \\
\pm 0.70\end{array}$ & $\begin{array}{r}1.94^{\mathrm{a}} \\
\pm 0.83\end{array}$ & $\begin{array}{c}0.99^{\mathrm{a}} \\
\pm 0.51\end{array}$ \\
\hline & Digested Jellyfish & $\begin{array}{l}27.34^{\mathrm{a}} \\
\pm 1.38\end{array}$ & $\begin{array}{l}19.30^{\mathrm{a}} \\
\pm 0.60\end{array}$ & $\begin{array}{c}8.04^{\mathrm{a}} \\
\pm 1.11\end{array}$ & $\begin{array}{l}3.29^{\mathrm{ab}} \\
\pm 0.16\end{array}$ & $\begin{array}{l}10.29^{\mathrm{a}} \\
\pm 0.58\end{array}$ & $\begin{array}{c}3.15^{\mathrm{a}} \\
\pm 0.44\end{array}$ & $\begin{array}{c}0.64^{\mathrm{a}} \\
\pm 0.26\end{array}$ \\
\hline & $\begin{array}{l}\text { Stock } \\
\text { Jellyfish } \\
\end{array}$ & $\begin{array}{r}20.2^{\mathrm{b}} \\
\pm 1.99 \\
\end{array}$ & $\begin{array}{l}15.38^{\mathrm{a}} \\
\pm 1.97 \\
\end{array}$ & $\begin{array}{r}4.82^{\mathrm{a}} \\
\pm 0.24 \\
\end{array}$ & $\begin{array}{c}2.60^{\mathrm{b}} \\
\pm 0.25 \\
\end{array}$ & $\begin{array}{r}7.60^{\mathrm{a}} \\
\pm 1.03 \\
\end{array}$ & $\begin{array}{r}4.94^{\mathrm{a}} \\
\pm 2.24 \\
\end{array}$ & $\begin{array}{r}0.15^{\mathrm{a}} \\
\pm 0.06 \\
\end{array}$ \\
\hline \multicolumn{2}{|r|}{ L.S.D 0.05} & 4.34 & 2.78 & 3.36 & 0.60 & 2.27 & 4.86 & 1.14 \\
\hline \multicolumn{2}{|r|}{$\mathbf{P}$} & ns & ns & Ns & ns & ns & ns & ns \\
\hline
\end{tabular}


Each value is the mean often replicates, \pm : Standard Error,a,b,c: Significant among treatment

\section{C-Effect of Jellyfish Soaking on Photosynthetic Pigments}

The carotenoids value in control wheat seedlings is $4.33 \mathrm{mg} / 100 \mathrm{~g}^{-1}$; this value decreased to 1.88 and $1.85 \mathrm{mg} / 100 \mathrm{~g}^{-1}$ in digested or stock jellyfish, respectively. The same trend occurred in chlorophyll (a) of wheat where its values decreased to 4.79 and $6.26 \mathrm{mg} / 100 \mathrm{~g}^{-1}$ in digested or stock jellyfish compared to control value $7.46 \mathrm{mg} / 100 \mathrm{~g}^{-1}$. Also, chlorophyll (b) in respect to fresh weight was $4.65 \mathrm{mg} / 100 \mathrm{~g}^{-1}$ this value decreased to 2.38 and $2.97 \mathrm{mg} / 100 \mathrm{~g}^{-1}$ when wheat seeds soaked in digested or stock jellyfish. While the opposite trend were observed in chlorophyll (a) and carotenoid of lentil, it increased in digested or stock jellyfish compared to that of control Table (3). On the other hand, soaking lentil in digested jellyfish increased chlorophyll (b) to $0.48 \mathrm{mg} /$ $100 \mathrm{~g}^{-1}$ and decreased to $0.01 \mathrm{mg} / 100 \mathrm{~g}^{-1}$ in seedlings from seeds soaked in stock jellyfish as compared by control value $0.29 \mathrm{mg} / 100 \mathrm{~g}^{-1}$, as mentioned in the same table.

Table 3. Effect Of Soaking In Stock Or Digested Jellyfish Solution On Photosynthetic Pigments Mg/ 100gfresh Weight In Wheat And Lentil Leaves

\begin{tabular}{|c|c|c|c|c|}
\hline \multirow{4}{*}{ Wheat } & $\begin{array}{l}\text { Pigments } \\
\text { Treatments }\end{array}$ & Chlorophyll a & Chlorophyll b & Carotenoids \\
\hline & Control & $\begin{array}{c}7.46^{\mathrm{a}} \\
\pm 0.08\end{array}$ & $\begin{array}{l}4.65^{\mathrm{a}} \\
\pm 0.00\end{array}$ & $\begin{array}{c}4.33^{\mathrm{a}} \\
\pm 0.08\end{array}$ \\
\hline & Digested Jellyfish & $\begin{array}{c}4.79^{\mathrm{b}} \\
\pm 0.08\end{array}$ & $\begin{array}{l}2.38^{\mathrm{a}} \\
\pm 0.01\end{array}$ & $\begin{array}{c}1.88^{\mathrm{a}} \\
\pm 0.06\end{array}$ \\
\hline & Stock Jellyfish & $\begin{array}{c}6.26^{\mathrm{b}} \\
\pm 0.08\end{array}$ & $\begin{array}{c}2.97^{\mathrm{a}} \\
\pm 0.11\end{array}$ & $\begin{array}{c}1.85^{\mathrm{a}} \\
\pm 0.29\end{array}$ \\
\hline & L.S.D ${ }_{0.05}$ & 0.27 & 0.22 & 0.62 \\
\hline & $\mathbf{P}$ & $*$ & ns & $\mathrm{ns}$ \\
\hline \multirow{3}{*}{ Lentil } & Control & $\begin{array}{c}0.63^{\mathrm{a}} \\
\pm 0.10\end{array}$ & $\begin{array}{c}0.29^{\mathrm{a}} \\
\pm 0.09\end{array}$ & $\begin{array}{c}0.17^{\mathrm{a}} \\
\pm 0.01\end{array}$ \\
\hline & Digested Jellyfish & $\begin{array}{c}1.87^{\mathrm{a}} \\
\pm 0.07\end{array}$ & $\begin{array}{c}0.48^{\mathrm{a}} \\
\pm 0.02\end{array}$ & $\begin{array}{c}0.74^{\mathrm{a}} \\
\pm 0.07\end{array}$ \\
\hline & Stock Jellyfish & $\begin{array}{c}0.92^{\mathrm{a}} \\
\pm 0.07\end{array}$ & $\begin{array}{c}0.01^{\mathrm{a}} \\
\pm 0.01\end{array}$ & $\begin{array}{c}0.92^{\mathrm{a}} \\
\pm 0.05\end{array}$ \\
\hline \multicolumn{2}{|r|}{ L.S.D ${ }_{0.05}$} & 0.27 & 0.18 & 0.18 \\
\hline \multicolumn{2}{|r|}{$\mathbf{P}$} & ns & ns & ns \\
\hline
\end{tabular}

Each value is the mean of three replicates; \pm Standard Error; a, b, c: Significant among treatment

\section{D- Effect of jellyfish soaking on mineral and heavy metals}

Soaking wheat and lentil seeds in digested or stock Jellyfish affected on mineral concentrations of seedlings; some minerals decreased and other increased. Table (4) showed that the concentrations of copper, chromium, zinc, sulfur and potassium decreased in wheat seedlings resulted from seeds soaked in digested or stock Jellyfish; as compared to control. Other minerals which are essential for plants cell construction in wheat seedlings as magnesium, iron, nitrogen, phosphorus, calcium and sodium increase above the control seedling. Most of aforementioned elements were considered as an activator of many enzymes that are essential for photosynthesis and respiration. It also, activates enzymes needed to form starch and proteins. Beside the familiar function of $\mathrm{Mg}^{2+}$ as central ion in chlorophyll molecule, it is essential because it combines with ATP (thereby allowing ATP to function in many reactions) and because it activates many enzymes needed in photosynthesis, respiration and formation of DNA and RNA (Salisbury and Ross,1992).

TABLE 4. Effect of Soaking in Stock or Digested Jellyfish Solution on Minerals Concentrations $\mathrm{mg} / \mathrm{Kg}^{-1}$ Dry Weigh in Wheat and Lentil Seedlings

\begin{tabular}{|l|c|c|c|c|c|c|c|}
\hline \multirow{2}{*}{ Element } & \multirow{2}{*}{$\begin{array}{c}\text { Digested } \\
\text { Jellyfish }\end{array}$} & \multicolumn{3}{|c|}{ Wheat } & \multicolumn{3}{c|}{ Lentil } \\
\cline { 3 - 8 } & & Control & Digested & Stock & Control & Digested & Stock \\
\hline Copper (Cu) & - & 25.1 & 2.109 & 5.517 & 21.3 & 3.995 & 2.824 \\
\hline Chromium (Cr) & - & 8.3 & 0.083 & 1.577 & 7.3 & - & - \\
\hline Cadmium (Cd) & - & 0.13 & 0.179 & 0.155 & - & - & 14.177 \\
\hline Zinc (Zn) & 0.58 & 73.2 & 10.45 & 19.577 & 70.6 & 12.238 \\
\hline Manganese (Mn) & - & 127.9 & - & - & 167.8 & - & - \\
\hline Magnesium (Mg) & 169 & 127.9 & 160.87 & 160.87 & 18568.5 & 1172910.3 & 2769801.3 \\
\hline Lead (Pb) & LOQ & - & - & - & - & - & - \\
\hline Iron (Fe) & 1.3 & 5173.6 & 5648.5 & 5048.6 & 8486.4 & 11937.7 & 28744 \\
\hline
\end{tabular}


Effect of soaking in Jellyfish on some parameters of wheat and lentil seedlings

\begin{tabular}{|l|c|c|c|c|c|c|c|}
\hline Nitrogen (N) & - & 0.5 & 14.00 & 19.50 & 13.00 & 14.00 & 14.00 \\
\hline Phosphorus (P) & 2.26 & 3.64 & 6.64 & 7.40 & 7.70 & 8.57 & 8.15 \\
\hline Calcium (Ca) & 34.62 & 2.69 & 4.94 & - & 6.27 & 6.37 & 5.46 \\
\hline Sodium (Na) & 254 & 1345 & 1710 & 1710 & 980 & 980 & 630 \\
\hline Potassium (K) & 254 & 3010 & 3010 & 2040 & 2520 & 2040 & 1070 \\
\hline Sulfur (S) & 11.23 & 15.69 & 15.64 & 11.64 & 11.04 & 11.50 & 11.91 \\
\hline Chlorine (Cl) & 0.1775 & - & - & - & - & - & - \\
\hline
\end{tabular}

(LOQ): Limits of quantification (from the list $=6.67 \mu \mathrm{g} / \mathrm{kg}$ ), the estimation relative standard deviation is $<15 \%$

(-) undetected

On the other hand, manganese was undetected in treated seeds. Sulfur (S) in large amount, may be retained in the tissues and cell sap in many plants without injury. In reduced form, $(\mathrm{S})$ occurs in such compounds as cystine, methionine, thiamine and biotin. It is known to be essential for nodular formation on legumes roots and deficiency retards cell division and fruiting in some species.

Phosphorus is classified as a major plant nutrient and considered essential for seed growth and stimulant for root growth. It was observed that Iron constituted the major element in wheat seedlings arise from treated or untreated seeds. Iron increase by $9.18 \%$ in digested treatment but decrease in stock as compared to control. Also, calcium increased in wheat seedlings soaked as seeds in digested Jellyfish by $83.64 \%$ as compared to control. Iron is essential elements because it forms parts of certain enzymes and numerous proteins that carry electrons during photosynthesis and respiration. The importance of iron in electron transport processes in plants was reviewed by Sandman and Boger, 1983. Calcium appears to be closely related to the growth of apical meristems and to the formation of flowers. On the other hand, the major element in lentil samples was magnesium where its value duplicated many times comparing to control value. But, Manganese was undetected in digested and stock treatment in wheat and lentil seedlings. Minerals composition of lentil seedlings increased in some minerals composition as magnesium, iron, nitrogen and phosphorus; in digested and stock jellyfish, respectively compared to control values. Whereas; chromium and manganese disappeared in lentil seedlings arise from seeds soaked in Jellyfish. On the other hand, sodium element had the same value as control in lentil seedlings soaked as seeds in digested Jellyfish, whereas; the same element decreased in those soaked as seeds in stock Jellyfish. The stock and digested treatments in wheat have the same nitrogen content whose values higher than in control value as illustrated in Table (4). Hossain, et al. (2013) concluded that desalinated-dried jellyfish has potential as an agricultural material that replaces herbicides and chemical fertilizers. It also contributes to environment-friendly rice production. The grain yields of desalinated-dried jellyfish treatments were consistently higher than the corresponding rice bran treatments.

\section{E- Effect of Jellyfish soaking on leaf ultrastructure}

The possible changes in the cell organelles such as mitochondria, chloroplast, nucleus and the cell wall were considered and examined by transmission electron microscopy (TEM).

\section{Wheat ultrastructure}

The cell wall in leaf cell examined from seedling of control treatment covered with a thin layer of cuticle and surface stomata. The vascular bundle which represents stem elongation as midrib in wheat leaf seems smaller than that in digested treatment (picture b). Also, spongy tissues in mesophyll layer enclosed larger intercellular space, less nutrient and plastids. Regarding to cell wall in picture (b), notice the presence of thick layer of cuticle covered upperlayer of cell wall. Xylem in vascular bundle seems larger than in control one; this
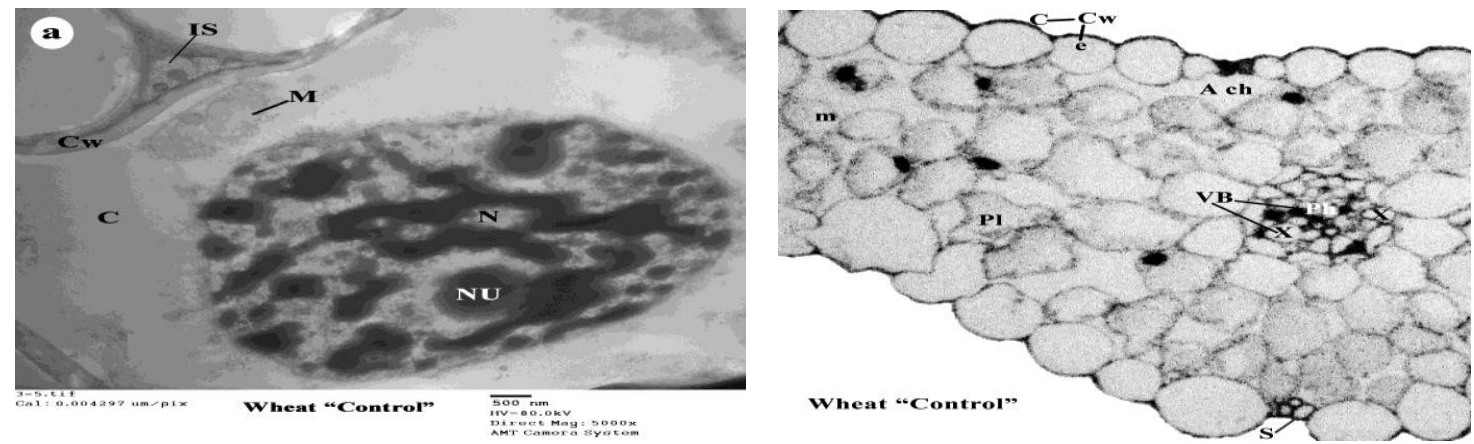

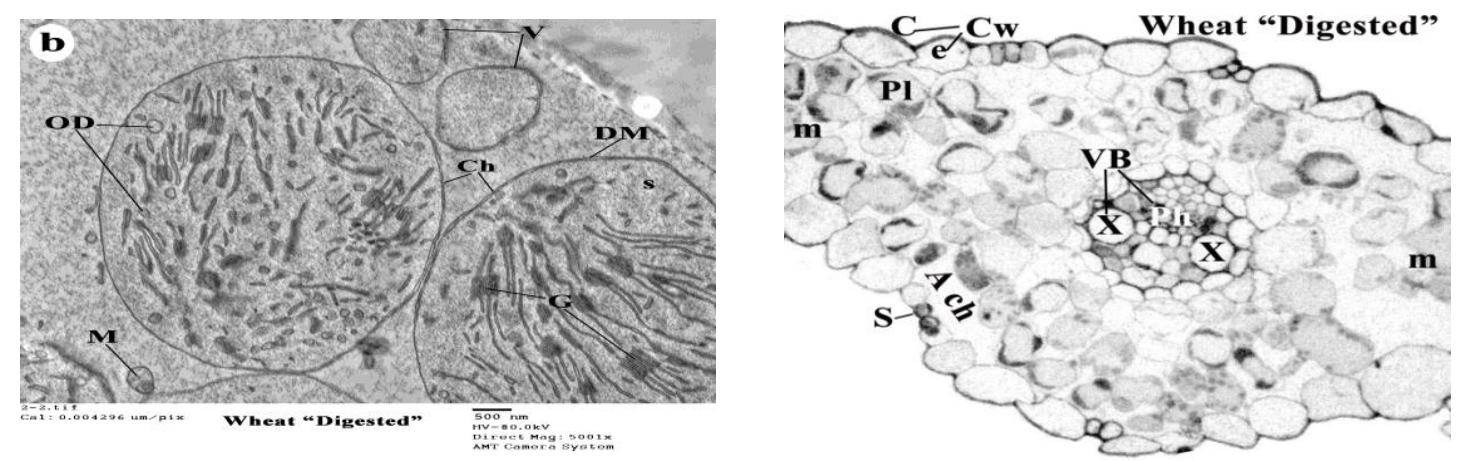

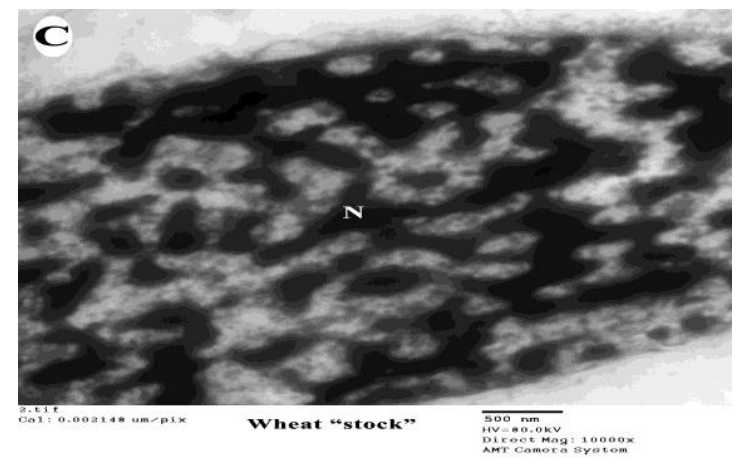

Electron micrographs

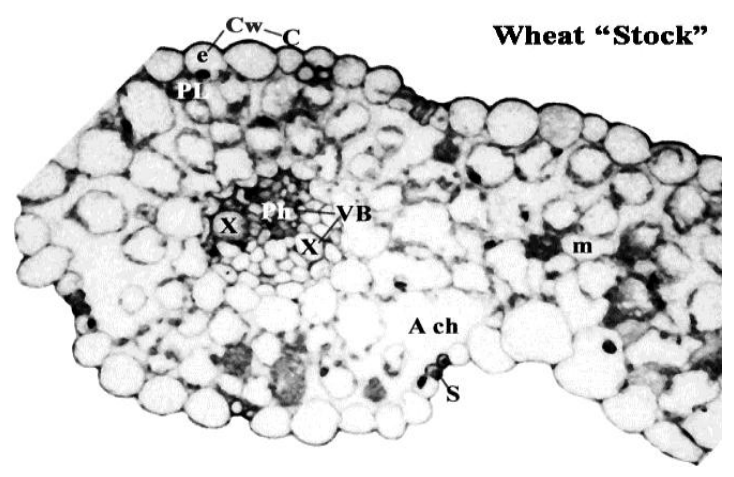

Light micrographs

Fig1. Transmission electron micrographs and cross section of wheat leaf as affected bysoakingtreatments in stock or digested jellyfish solutions.

Keywords: A ch: Air chamber, C: cytoplasm, c: cuticle, Cw: cell wall, e: endodermis, G: Grana, m: mesophyll, M: Mitochondria, N: nucleus, S: stomata, s: stroma, pl: plastid, ph: phloem, V: vacuole, VB: vascular bundle, x: xylem.

May help in more translocation of food and water from soil. Also, intercellular space was small and this may attribute to space in spongy tissue which appears turgid with nutrients and water as shown by dense colors. Electron micrograph of lentil leaf from seeds soaked in stock jellyfish picture (c) resemble picture (a) from seeds soaked in water.

Electron micrograph in (Fig.1 b) show a large number of structureless microbodies in the cell called peroxisome. Peroxisomes are localized within the cell of picture $\mathrm{b}$ in close association with chloroplasts. Picture (b) show mature chloroplast that consistsof double membrane envelop, granum, granum lamella and stroma includes osmophilic droplets, protein and starch grains. In the lower corner of picture b observe the chloroplast envelope ruptured and stroma dispersed throughout the cell's interior. The presence of mature chloroplast means that soaking wheat seeds in digested jellyfish solution activatesphotosynthesis process. Meanwhile the ultrastructure of leaf from seedling (c) produced from seeds soaked in liquefied jellyfish doesn'tdiffer from control. Transmission electron micrograph in control wheat cell contains large nucleus, nuclear materials as unorganized chromatin and three nucleoli, mitochondria and cell wall also appear in (Fig.1 a). We never observed any degradation or mutation, cell organelles seems normal. There are several reports on the microscopic effects of organic pollution on plants (Minai-Tehrani and Mohammadi 2014; Brandt et al. 2006). Shdunishvili et al. 2009 have focused the microscopic level and also biochemical changes in plant.

\section{Lentil Ultrastructure}

Prior to the electron microscopic observation, we investigated the semi thin sections obtained with ultramicrotome. Endodermis layer appears more compact and smaller in size in picture b and c. The cytoplasm in control lentil contains endoplasmic reticulum and all main cellular organelles, mitochondria, vesicles and ribosome. Ribosomes are associated with membrane of the endoplasmic reticulum. Two populations of ribosomes are present in cells. One group is attached to endoplasmic reticulum (Fig.2 a,c) and known as rough endoplasmic reticulum. Other ribosomes present freely within the cytoplasm (Fig.2 b). No, deformation or abnormalities in organelles or cell wall in leaf from treated seeds. 

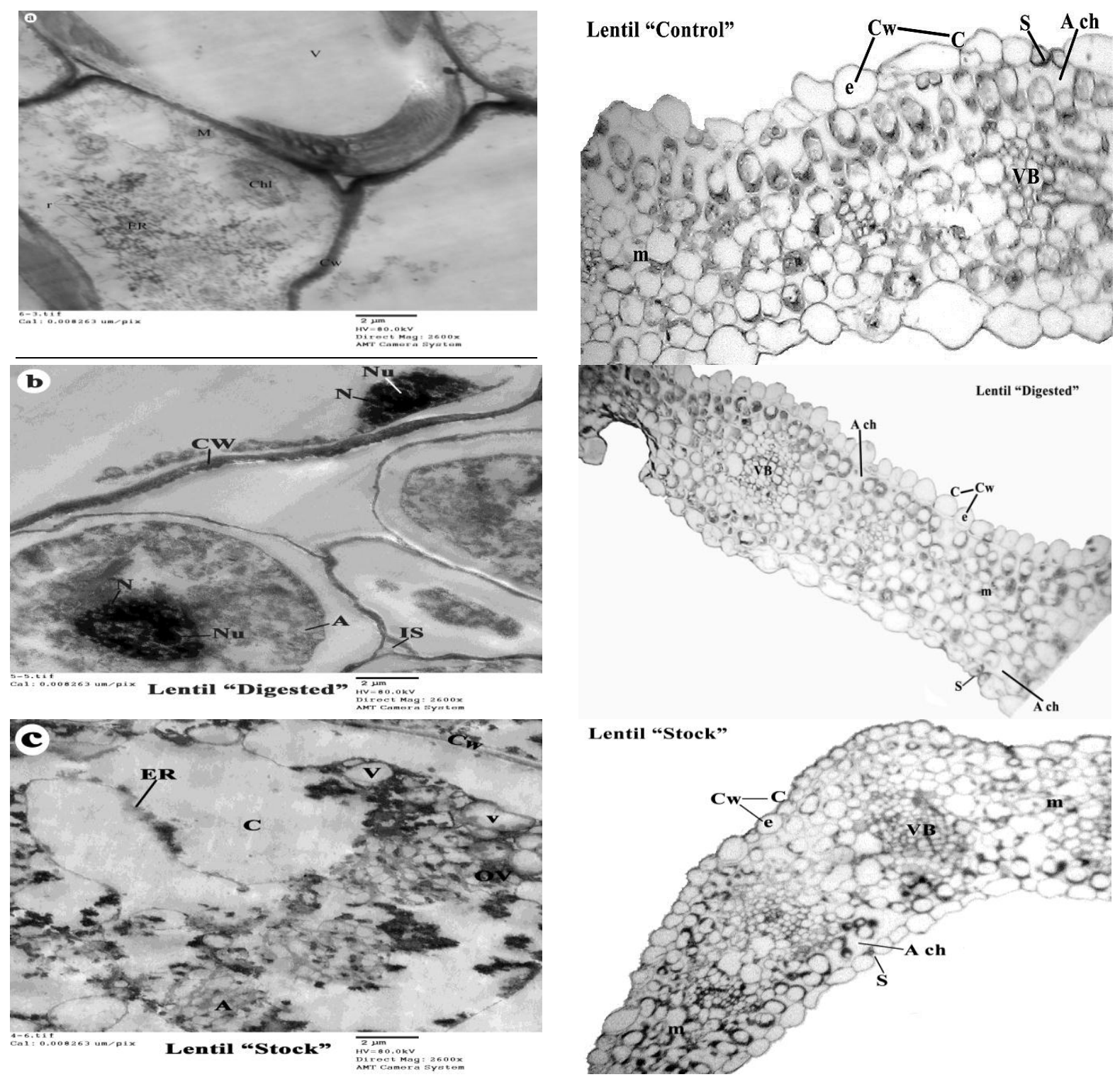

Electron micrographs

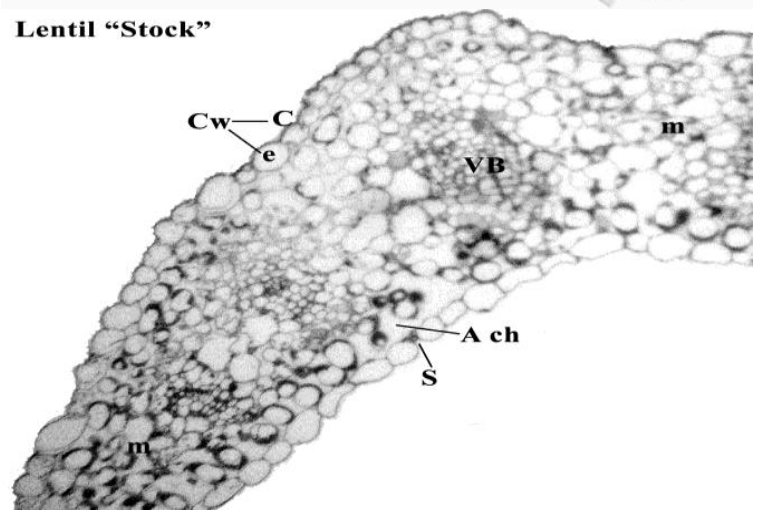

Light micrographs

Fig. 2. Transmission electron micrographs and cross section of Lens culinaris leaf as affected by soaking treatments in stock or digested jellyfish solutions.

Keywords: A: amyloplast, A ch: Air chamber, C: cytoplasm, Cw: cell wall, m: mesophyll, M: Mitochondria, N: nucleus, S: stomata, pl: plastid, VB: vascular bundle, V: vacuole, ov:osmiophilic vesicles v: vesicles, $\mathrm{r}$ : ribosome, ER: endoplasmic reticulum

\section{Conclusion}

This experimentmonitored the effect of liquefied or digested jellyfish solution on cellular and minerals changes in the wheat and lentil seedlings. No, deformation or abnormalities in organelles orcell wall in leaf from treatedseeds. The resistant physiological changes in the leaves of wheat or lentil, in response to soaking in stock or digested jellyfish can be used as indicators for treatment. Jellyfish may be used as growth promoter, but it needs further investigation.

\section{References}

[1]. K.Fukushi, K. Yokota and J. Tsujimoto Preliminary study onthe preparation of fertilizer utilizing jellyfish. Ann. Res. Rep., 5, 2003, 308-311.

[2]. K.Fukushi, N.Ishio, J.Tsujimoto, K.Yokota, T.Hamatake, H.Sogabe, K. Toriya and T. Nimomiya Preliminary Study on the Potential usefulness of Jellyfish fertilizer. J. Bullet. Soc. Sea Water Sci., Japan, 58, 2, 2004, 209-217.

[3]. G. H. MahranPlant nutrient and plant hormones In: "Principles of General Phrmacogenosy" Chapter VII, 1972, 69.

[4]. K.Mengel, E.A.Kirk, H.Kosegarten, T. Appel Principles of plant nutrition2001. Kluwer Academic Publisher, Dordrecht, The Netherlands.

[5]. H.Marshner. Minerals nutrition of higher plants, $2^{\text {nd }}$ edn1995. Academic Press, London UK. 
[6]. S.M. Bokhtair and, K.Sakurai (2005) Effects of organic manure and chemical fertilizer on soil fertility and productivity of plant and ratoon crops of sugarcane. Archives of Agronomy and Soil science, 51, 3, 334-325.

[7]. S.T.Hossain, H.Sugimoto, N.Asagi,, T.Araki, H.Ueno, M. Morokuma and, H.Kato. The use of desalinated-dried jellyfish and rice bran for controlling weeds and rice yield. J. Org. Syst., 8 (1) 2013, 28-37.

[8]. E.K.Ryan Galvin, T.P.O. Connor, A.R. Maguire and N.M.O. Brien, Phytosterol squalene, tocopherol content and fatty acid, profile of selected seeds, grains and legumes. Plant foods Hum. Nutr., 62,2007, 85.

[9]. H.Metzner, H. Rau and H. Senger Unterschunger Zur Synchronisier Barkeit einzelner pigmenmangel. Mutantenvon chlorella, Planta, $65,1965,186$.

[10]. A.Sepe, L.Ciaralli, M.Ciprotti, R.Giordano, E. Funari and S. Cotsntini Determination of Cadmium, Chromium, Lead and Vanadium in six fish species from the Adriatic Sea Shore. Food Addet. Contam., 20, 6, 2003, 543-552.

[11]. C.A. Black, D.D.Evans, J.L.White,L.E. Ensiminger andF.E. Clark Methods of Soil Analysis. Amer. Soc. Agron. Inc.,(1982) Ser. 9 in Agron. Madison, Wisconsin.

[12]. P.N. Soltanpour Determination of nutrient availability and elemental toxicity by AB-DTPA soil test and ICPS. Adv. Soil Sci.,16, 1991, 165-195.

[13]. M.L. Jackson Soil Chemical Analysis. Prentice Hall of India Pvt. Ltd, New Delhi1973.

[14]. W.B. McGill and C.T. Figueiredo Total nitrogen. In: Carter, M.R. (Ed.), Soil Sampling and Methods of Analysis. Canadian Society of Soil Science/Lewis Publishers, 1993, pp. 201-211.

[15]. D.BDuncan.(1955) Multiple ranges and multiple F.test. Biomerics., 11, 1.

[16]. K.W.Chun, E.Damdinsuren, K. Yeom and, T.Ezaki Effect of Jellyfish Fertilizer Application on Seedling Growth. J. Jpn. Soc. Reveget. Tech., 37 (1)2011, 155-158.

[17]. F. B.Salisbury and C.W. Ross Plant Physiology. $2^{\text {nd }}$ ed. Mineral Nutrition Chap. 6,1992, 116-135, Wadsworth Publishing Company, Belmont California.

[18]. G Sandman and P. Boger The enzymological function of heavy metals and their role ion electrontransfer processes of plants. P. 563596 In: A. Laüchli and R.L. Bieleski (eds). Encyclo. Plant Phys., New Series, vol. 15B, 1983, Inorganic plant nutrition. SpringerVerlag, Berlin.

[19]. D. Minai-Tehrani and, M.K. Mohammadi crude oil-polluted soil induces ultrastructure and enzyme activity changes in the shoot of lentil. J. str. Physio. Bioch., 10, 1,2014, 112.

[20]. R.Brandt, N.Merkl, R.Schultze-Kraft, C.Infante and G.Broll (2006) Potential of vetiver [Vetiveria zizanoides (L.) Nash] for petroleum hydrocarbon-contaminated soils in venzuela. Int. j. phytoremediation, 8, 4, 273-284.

[21]. T. Shdunishvili, E. Kvesitadze, M. Betsiashvili, N. Kuprava, , G. Zaalishvil, , G. KvesitadzeInfluence of hydrocarbons on plant cell ultrastructure and main metabolic enzymes. World acade.Sci., Engin. Tech., 57,2009,271-276. 